\title{
How Corporate Social Responsibility and External Stakeholder Concerns Affect Green Supply Chain Cooperation among Manufacturers: An Interpretive Structural Modeling Analysis
}

\author{
Xiangmeng Huang $\mathbb{D}$, Shuai Yang *(D) and Xiaolan Shi \\ Business School, Changshu Institute of Technology, Changshu 215500, China; \\ xiangmeng.huang@cslg.edu.cn (X.H.); sxl@cslg.edu.cn (X.S.) \\ * Correspondence: 201500001@cslg.edu.cn; Tel.: +86-0512-5225-1817
}

Citation: Huang, X.; Yang, S.; Shi, X. How Corporate Social Responsibility and External Stakeholder Concerns Affect Green Supply Chain Cooperation among Manufacturers: An Interpretive Structural Modeling Analysis. Sustainability 2021, 13, 2518. https://doi.org/10.3390/su13052518

Academic Editor: Sebastian Kot

Received: 4 February 2021

Accepted: 23 February 2021

Published: 26 February 2021

Publisher's Note: MDPI stays neutral with regard to jurisdictional claims in published maps and institutional affiliations.

Copyright: (c) 2021 by the authors. Licensee MDPI, Basel, Switzerland. This article is an open access article distributed under the terms and conditions of the Creative Commons Attribution (CC BY) license (https:// creativecommons.org/licenses/by/ $4.0 /)$.

\begin{abstract}
The past decade saw an increasing development and improvement of green supply chain, but the environmental performances cannot be achieved by single enterprises. Therefore, it is necessary to find out the influencing factors that hinder the cooperation of green supply chain, so as to make full use of these influencing factors to improve environmental performance. In consultation with supply chain management practitioners and academics, this paper establishes a set of 19 influencing factors for green supply chain cooperation among Chinese manufacturers The corporate social responsibility as internal effect and external stakeholder concern as external effect is considered in this study and the interpreted structural model (ISM) method is used to analyze the interaction among these influencing factors and its impact on green supply chain cooperation. This study aims to identify the most significant impacts on environmental issues with supply chain partners and to understand how these impacts can help improve the environmental performance throughout the supply chain.
\end{abstract}

Keywords: green supply chain cooperation; corporate social responsibility; external stakeholders; interpretive structural modeling

\section{Introduction}

Green supply chain (GSC) has drawn increasing attention among enterprises and scholars worldwide over the past few decades with the increased environmental consciousness. For example, 74 cities of China reported that the annual mean PM2.5 concentrations exceeded the WHO air quality guideline for PM2.5 over the past 5 years. Air quality in 217 cities failed to meet environmental air quality standards, accounting for $64.2 \%$ of the total monitored cities in 2018 [1]. Manufacturing industry has been claimed to be responsible much for the environmental issues of global warming, desertification, acid rain pollution, and so on. With the multiple purposes of achieving cost reduction, economic growth and environmental friendship, a number of manufacturing enterprises have been pressured to establish networks of their suppliers to increase their environmental performance [2,3].

Supply chain plays an important role in greening manufacturers for two reasons. Firstly, supply chain has a strong relationship with the natural environment as it deals with the required resources for the manufacturing production [4]. According to Srivastava [5], supply chain is believed to have a deep impact on the exploitation of resources both renewable and nonrenewable. The close link to resources and environment illustrates the importance of incorporating green supply chain into internal feasibility. Secondly, the environmental perception and ability of the manufacturing suppliers can be influenced through the purchasing practices of the supply chain. It is believed that large manufacturers could use their purchasing power to help implant environmental responsibility and green actions in those small and medium-sized businesses across the supply chain $[2,6]$. The 
ineluctable association proposes the importance of integrating green supply chain in external necessity.

Previous research on green supply chain extensively discusses how the manufacturing sector has embraced green efforts in business operations [7-9]. It is proposed that greening of the supply chain is one of the most valued aspects that is fast gaining attention among manufacturers to develop their environmental performance [10]. Furthermore, those effective green supply chain implementations can help enhance their competitive advantage [11,12]. However, enterprises cannot overcome environmental challenges on their own and concerted efforts are needed to integrate environmental considerations into their business decisions [13]. Existing studies point out that cooperation plays a critical role for businesses in greening their supply chains and achieving their targeted enterprise objectives, which would bring positive outcomes such as building a stronger and more sustainability oriented manufacturer [14,15]; planning coordination of green product design [16,17]; recycling used products [18]; reducing $\mathrm{CO}_{2}$ emissions throughout the business operations like production and logistics [19]; marketing greener products [20,21]; gaining customer satisfaction and trust [22]; as well as maximizing the chain-wide profit [23,24]. However, there is little research in the existing literature on how green supply chain cooperation affects environmental operations in the manufacturing industry.

Thus, considering both the internal and external necessity, this study is intended to address this gap. With an extensive literature review of green supply chain, the authors identified 19 influencing factors in terms of corporate social responsibility (CSR) as internal effects and external stakeholder concerns as external effects on cooperating with upstream and downstream suppliers to be environmentally friendly throughout the supply chain; meanwhile, 17 manufacturers were chosen in China to use the interpreted structural model (ISM) technique through experts' judgments. The remainder of this paper is organized as follows: in Section 2, a literature review presents the green supply chain development and identifies the internal and external effects for cooperation in manufacturing industry. Section 3 introduces the ISM methodology and explains how it is used in this study. In Section 4, this paper summarizes the findings of the study and presents a discussion of the research results. Conclusions are drawn in Section 5.

\section{Literature Review}

\subsection{Going Green in Supply Chain}

The term of supply chain was first introduced by Oliver and Webber in the early 1980s which has traditionally been regarded as the process of converting raw materials into final products which will then be transferred to the end users [25]. In addition to tangible product flow, some researchers have also stressed the intangible value of the information flow through the supply chain, which includes an emphasis on market needs exchange, trust building, product development, supplier base reduction, strategic positioning leverage, and operating efficiency improvement. Information cooperation between supply chain partners makes supply chain structure more complex and more efficient [26]. Furthermore, Welford [27] proposed that the supply chain relationship has definitely become more critical in today's globalized world, in light of the growing notion of environmental responsibility around the world. Actually, it is important to note that we are entering into an era where green issues have become an important element in business practices.

Empirical evidence also shows that customers as one of the external stakeholders are increasingly eager to understand the conditions where products have been manufactured $[28,29]$. Moreover, they are increasingly inclined to consume desirable products that are produced in an environmentally sustainable way [30]. Therefore, the manufacturers make great efforts to provide green products by investing and developing green technology to produce and transfer green products and determining the greenness of the products as well as to fulfill their CSR in terms of environmental responsibility [31]. 
As a result, greening the supply chain would involve the philosophy and practices throughout the whole manufacturing flow in consideration of both internal CSR and external stakeholders. It includes the inbound processes like cultivating and encouraging suppliers to share environmental difficulties and know-how with each other, acquainting suppliers with the benefits of cleaner production, stressing the importance of green actions to suppliers and selecting suppliers based on environmental criteria; the processive production such as environmentally friendly materials use, green design considerations, waste reduction, cleaner technology adoption, and internal materials recycling; the outbound processes like waste management, green packaging improvement, eco-labeling, product recovery, and so on [32]. In addition, Hoek and Remko [33] also emphasize that it is significant for the manufacturers to green the supply chain by promoting synergy with their partners.

\subsection{Green Supply Chain Cooperation}

There is an increasing awareness among businesses that it is not adequate to achieve green supply chain objectives by working alone [34]. Walton et al. [35] verified that it is beneficial for the manufacturers to influence their suppliers by putting effects in the purchasing process. Barratt [36] and Danese [37] believed that a number of businesses worldwide have benefited from supply chain cooperation to reduce cost and increase environmental performances. Subramanian et al. [16] pointed out that manufacturers would have different choices for product design as they have different levels of cooperation with their downstream partners. These studies reveal that environmental improvement is achievable through the cooperation with suppliers in the chain.

However, recent research proposes the idea that difficulty is arising in the supply chain in terms of cooperation because of the increasing complexity within the supply chain network [20]. Moreover, the increased sophistication of the supply chain has given rise to several tools for supply chain cooperation, but few of them have taken reduction of carbon or greenness of production into consideration [38]. It is also notable that different participants in the supply chain have different interest demands for the level and content of cooperation. For example, some supply chain partners seek a high level of cooperation with the exchange of transparent information between each other while others may prefer a low level of cooperation in product design and development; thus, different interest demands of cooperation involving green issues will emerge for different supply chain partners [39]. Therefore, it is necessary to figure out what are the decisive factors of suppliers to work or cooperate together for a green supply chain.

\subsection{Influencing Factors for Green Supply Chain Cooperation: CSR and External Stakeholders}

Literature survey has thrown light on some of the motivations which drive businesses for green supply chain cooperation, but little carefully designed research has explained the system. In this study this research gap is identified and a set of 19 influencing factors for the cooperation of green supply chain in 17 manufacturing enterprises in China are considered. Those factors can be categorized into two groups in terms of the feasibility and necessity of green supply chain and they are CSR and external stakeholders' concerns.

CSR is regarded as the internal effects which are related to the voluntary proactive strategies to gain a competitive advantage as well as stronger purchasing power, improve corporate image and brand, fulfill the anticipated social responsibility, and draw attention from environmentally conscious customers; to share environmental management information, know-how and technologies with supply chain partners; to cope with production through energy-saving and emission-reduction. These influencing factors could be generally explained using Resource Based View (RBV) [40,41].

External stakeholders' concerns derive from end-users who are interested in environmentally friendly products. Supply chain partners who are more concerned with environmental management, government, community, and other stakeholders with stricter legal demands and requirements in line with the growing concerns for environmental 
protection and resource utilization have all exerted a variety of pressures. The inclusion of such effects is mainly explained through an institutional theory which identifies three types of institutional pressures, including normative, mimetic, and coercive ones.

In total, 19 factors including both CSR and external stakeholders' concerns are described in Table 1 based on literature and discussions with industrial experts and academicians, from which influencing factors 1-12 are based on CSR concerns and factors 13-19 are with regard to external stakeholders' concerns.

Table 1. Description of influencing factors for green supply chain cooperation.

\begin{tabular}{|c|c|c|c|}
\hline & Influencing Factors & Description & Source \\
\hline 1 & $\begin{array}{l}\text { Information sharing and } \\
\text { transparency }\end{array}$ & $\begin{array}{l}\text { Information sharing through the communication systems } \\
\text { along the supply chain can be seen as the enabling } \\
\text { resources for the development of green capacities within } \\
\text { the enterprise as well as across the partners with } \\
\text { information exchange and transparency and the } \\
\text { cooperation up and down the supply chain. }\end{array}$ & $\begin{array}{l}\text { Hervani et al., 2005; Melville, 2010; } \\
\text { Fawcett et al., 2011; Cai et al., 2016 [42-45] }\end{array}$ \\
\hline 2 & $\begin{array}{l}\text { Purchasing power } \\
\text { enhancement }\end{array}$ & $\begin{array}{c}\text { The purchasing strategy of environmental issues' } \\
\text { involvement enables the enterprises to define an action } \\
\text { plan towards suppliers for green purchases. }\end{array}$ & $\begin{array}{l}\text { Handfield et al., 2010; Large and Thomsen, } \\
\text { 2011; Walker and Jones, } 2012 \text { [46-48] }\end{array}$ \\
\hline 3 & $\begin{array}{l}\text { Top management } \\
\text { commitment }\end{array}$ & $\begin{array}{l}\text { The commitment from the top management of an } \\
\text { enterprise allows for the devotion of the necessary } \\
\text { resources for green cooperation through the supply chain. }\end{array}$ & $\begin{array}{l}\text { Bowen et al., 2001; Pujari et al., 2004; } \\
\text { Pagell and Wu, 2009; Hofer et al., 2012; } \\
\text { Rehman et al., } 2016 \text { [49-53] }\end{array}$ \\
\hline 4 & $\begin{array}{l}\text { Knowledge management } \\
\text { and sharing }\end{array}$ & $\begin{array}{l}\text { Knowledge management encourages learning, sharing and } \\
\text { spreading environmental knowledge and technical green } \\
\text { initials between enterprises across the chain. }\end{array}$ & $\begin{array}{l}\text { Zhu et al., 2004; Cheng et al., 2008; Gmelin } \\
\text { and Seuring, 2014; Lee, } 2015 \text { [54-57] }\end{array}$ \\
\hline 5 & $\begin{array}{l}\text { Green technology } \\
\text { integration }\end{array}$ & $\begin{array}{l}\text { Technological integration with primary suppliers and } \\
\text { major customers is believed to be positively linked to } \\
\text { environmental performance and cooperation. }\end{array}$ & $\begin{array}{l}\text { Vachon and Klassen, 2006; Gmelin and } \\
\text { Seuring, } 2014[34,56]\end{array}$ \\
\hline 6 & $\begin{array}{l}\text { Trustful suppliers' } \\
\text { selection }\end{array}$ & $\begin{array}{c}\text { Trust is vital in the cooperation between supply chain } \\
\text { partners and the trustful suppliers will enhance their } \\
\text { commitment and investment for environmental issues, } \\
\text { which is the major consideration for enterprises to select } \\
\text { their suppliers. }\end{array}$ & $\begin{array}{c}\text { Zhu and Sakis, 2004; Cheng et al., 2008; } \\
\text { Hoejmose et al., 2012; Hartmann and } \\
\text { Germain, } 2015 \text { [11,55,58,59] }\end{array}$ \\
\hline 7 & $\begin{array}{l}\text { Monitoring supplier } \\
\text { performance }\end{array}$ & $\begin{array}{c}\text { Evaluating and monitoring the performance of suppliers } \\
\text { on the basis of environmental criteria is positively linked } \\
\text { with the participation of suppliers in during the } \\
\text { cooperation across the chain. }\end{array}$ & $\begin{array}{l}\text { Zhu and Sarkis, 2004; Cheng et al., 2008; } \\
\text { Walker and Jones, 2012, Hartmann and } \\
\text { Germain, } 2015[11,48,55,59]\end{array}$ \\
\hline 8 & $\begin{array}{l}\text { Increased social } \\
\text { awareness }\end{array}$ & $\begin{array}{c}\text { Social awareness suggests that an enterprise is willing not } \\
\text { to take simple compliance but also take the public and } \\
\text { partners into consideration in terms of } \\
\text { environmental issues. }\end{array}$ & $\begin{array}{l}\text { Sharma, 2000; Seuring, 2004; Mudgal et al., } \\
\qquad 2010[60-62]\end{array}$ \\
\hline 9 & Maintaining green image & $\begin{array}{c}\text { Green image of an enterprises is believed as a driver for } \\
\text { implementation and cooperation of green supply } \\
\text { chain practices. }\end{array}$ & $\begin{array}{l}\text { Claver et al., 2007; Shang et al., 2010; } \\
\text { Gunasekaran and Spalanzani, } 2012 \text { [63-65] }\end{array}$ \\
\hline 10 & $\begin{array}{l}\text { Reduction in wastes and } \\
\text { emissions }\end{array}$ & $\begin{array}{c}\text { Wastes and emissions reduction will be directly achieved } \\
\text { through green supply chain cooperation. }\end{array}$ & $\begin{array}{l}\text { Tseng and Chiu, 2013; Scur and Barbosa, } \\
\qquad 2017[66,67]\end{array}$ \\
\hline 11 & $\begin{array}{l}\text { Effective and optimized } \\
\text { utilization of resources } \\
\text { and energy }\end{array}$ & $\begin{array}{c}\text { Improved energy and resources efficiency measures across } \\
\text { the supply chain can lead to reduction of } \\
\text { environmental impacts. }\end{array}$ & $\begin{array}{l}\text { Figge and Hahn, 2012; Thollander et al., } \\
\text { 2013; Liu et al., } 2017 \text { [68-70] }\end{array}$ \\
\hline 12 & $\begin{array}{l}\text { Gaining green } \\
\text { competitiveness }\end{array}$ & $\begin{array}{l}\text { Green supply chain cooperation should help enterprises to } \\
\text { enhance their competitive advantages with pollution } \\
\text { reduction, cost saving and productivity increase. }\end{array}$ & $\begin{array}{l}\text { Mittal et al., 2012; Henriques and Catarino, } \\
\text { 2016 [71,72] }\end{array}$ \\
\hline 13 & $\begin{array}{l}\text { Financial incentives from } \\
\text { government or } \\
\text { community }\end{array}$ & $\begin{array}{l}\text { Financial incentives are the important drivers for } \\
\text { enterprises to apply green supply chain practices as well as } \\
\text { cooperate with their supply chain partners. }\end{array}$ & Parker et al., 2009; Liu et al., $2017[70,73]$ \\
\hline 14 & $\begin{array}{l}\text { Stakeholders' green } \\
\text { concerns }\end{array}$ & $\begin{array}{l}\text { Pressures and impetus from stakeholders about } \\
\text { environmental issues help enhance the implementation of } \\
\text { green supply chain practices and cooperation. }\end{array}$ & $\begin{array}{l}\text { Claver et al., 2007; Zhu and Geng, 2013; } \\
\text { Lee et al., } 2015[7,63,74]\end{array}$ \\
\hline 15 & $\begin{array}{l}\text { Establishing long-term } \\
\text { relationship with supply } \\
\text { chain partners }\end{array}$ & $\begin{array}{l}\text { Effective green supply chain cooperation can be achieved } \\
\text { through long-term relationship with supply chain partners. }\end{array}$ & $\begin{array}{l}\text { Mentzer et al., 2001; Yang et al., 2008; Lee, } \\
\qquad 2015[4,57,75]\end{array}$ \\
\hline 16 & $\begin{array}{l}\text { Pressures of } \\
\text { environmental regulation } \\
\text { and legislation }\end{array}$ & $\begin{array}{c}\text { Implementation of legal mechanisms like regulations, } \\
\text { legislations and laws are effective to prevent polluting } \\
\text { industries from relocation and promote cooperation with } \\
\text { supply chain partners. }\end{array}$ & $\begin{array}{l}\text { Govindan et al., 2015; Zheng and Shi, } 2017 \\
{[76,77]}\end{array}$ \\
\hline
\end{tabular}


Table 1. Cont.

\begin{tabular}{|c|c|c|c|}
\hline \multicolumn{2}{|c|}{ Influencing Factors } & \multirow{2}{*}{$\begin{array}{l}\text { Description } \\
\text { Severe penalties are putting pressures on enterprises for } \\
\text { not performing green and to seek help and cooperation } \\
\text { with their supply chain partners. }\end{array}$} & Source \\
\hline 17 & $\begin{array}{l}\text { Penalties for the } \\
\text { noncompliance }\end{array}$ & & $\begin{array}{l}\text { Tseng and Chiu, 2013; Neto et al., } 2016 \\
{[666,78]}\end{array}$ \\
\hline 18 & $\begin{array}{l}\text { Customers' } \\
\text { environmental concern } \\
\text { increase }\end{array}$ & $\begin{array}{l}\text { The increasing green awareness of customers is valued by } \\
\text { the supplier chain partners and promotes their cooperation. }\end{array}$ & $\begin{array}{l}\text { Zhang et al., 2013; Hong and Guo, } 2018 \\
{[21,31]}\end{array}$ \\
\hline 19 & $\begin{array}{l}\text { Global quality } \\
\text { qualification acquisition }\end{array}$ & $\begin{array}{c}\text { Acquiring and applying the environmental qualifications } \\
\text { such as ISO } 9001 \text { and ISO 140,001 is believed to facilitate } \\
\text { the extension of green actions to other supply } \\
\text { chain partners. }\end{array}$ & $\begin{array}{l}\text { Handfield et al., 2010; Darnall et al., 2008; } \\
\text { de Sousa et al., 2014; Dubey et al., } 2015 \\
\text { [46,79-81] }\end{array}$ \\
\hline
\end{tabular}

\section{Research Methodology}

It is observed that few studies have discussed the influencing factors for green supply chain cooperation and for manufacturing industry. This study examines and prioritizes green supply chain cooperation influencing factors using the interpretive structural modeling approach which was developed as a communication tool for complex situations.

\subsection{Interpretive Structural Modeling (ISM)}

ISM is a learning method developed to reckon with a set of elements and their interactions that influence a complex phenomenon. It is interactive because it uses the experience, knowledge and judgment of experts for structuring whether and how the variables are related. Besides, it is structured because the diverse variables and their relationships are imposed with order and direction, leading to a better understanding of the complex phenomenon as a whole system. It is also interpretive as it is well designed to be represented in a graphical model with implying words [82-84]. The ISM method is generally applied through the steps as follows [85]:

Step 1. Variables (factors, elements or criteria) of the system under consideration are listed.

Step 2. A contextual relationship is established with the variables identified in the first step to determine which pairs of variables should be examined.

Step 3. A structural self-interaction matrix (SSIM) is constructed, indicating pairwise relationships among variables of the system under consideration.

Step 4. A reachability matrix (RM) is developed from the SSIM to be checked for transitivity. The transitivity is a basic assumption declaring that if a variable $\mathrm{A}$ is related to $B$ and $B$ is related to $C$, then $A$ is necessarily related to $C$.

Step 5. The RM developed in the previous step is partitioned into different levels.

Step 6. A direct graph is drawn based on the relationships given in the RM and the transitive links are removed.

Step 7. The resultant digraph is converted into an ISM with the replacement of variable nodes with statements.

Step 8. The ISM model is then checked for conceptual inconsistency and necessary modifications as well as commentary is made.

\subsection{Data Collection}

The influencing factors through the literature review were discussed with 17 supply chain management practitioners of middle-level management in different manufacturing enterprises in the southeast coastal area of China and it is the most prosperous manufacturing area in China. In addition, there were also discussions with five academicians and experts of supply chain management or environmental management from Chinese universities. The middle-level executives were selected because they are believed to be knowledgeable and progressive, and would be willing to facilitate adoptions of technology innovations or environmental management practices like greening the supply chain in which they are involved [86,87]. The industrial participants include three auto manufac- 
turers, four textiles manufacturers, three mechanical manufacturers, one paper mill, four pharmaceutical and two furniture producers.

The professional executives received the influencing factor list through direct visit or email and they firstly confirmed the 19 influencing factors with the interpretation identified in the literature review and then determined whether two of them were independent or interrelated in the application of the ISM protocol. All individual responses from the industry were collected and sent to the academic experts for discussions; one final response was consolidated and taken based on the sufficient discussions. Then the conclusion of the discussion results was consigned in the structural self-interaction matrix SSIM.

\subsection{Building Structural Self-Interaction Matrix (SSIM)}

With a "lead to" contextual relationship for each variable, the existence of a relation between any two influencing factors and the associated direction of the relation were used to construct the SSIM, shown in Table 2. Letters V, A, X, and O are used to denote the nature of the relationship between the factors ( $i$ and $j$ ):

V: Factor i will help achieve factor $\mathrm{j}$;

A: Factor $j$ will help achieve factor $i$;

$X:$ Factors $i$ and $j$ will help achieve each other; and

$\mathrm{O}$ : Factors $\mathrm{i}$ and $\mathrm{j}$ are independent.

Table 2. Structural self-interaction matrix (SSIM).

\begin{tabular}{|c|c|c|c|c|c|c|c|c|c|c|c|c|c|c|c|c|c|c|c|}
\hline $\begin{array}{l}\text { Influencing } \\
\text { Factors }\end{array}$ & 19 & 18 & 17 & 16 & 15 & 14 & 13 & 12 & 11 & 10 & 9 & 8 & 7 & 6 & 5 & 4 & 3 & 2 & 1 \\
\hline 1 & $\mathrm{~V}$ & $\mathrm{~V}$ & $\mathrm{O}$ & $\mathrm{A}$ & A & $\mathrm{A}$ & $\mathrm{A}$ & A & $x$ & $\mathrm{O}$ & $x$ & $\mathrm{~A}$ & $\mathrm{O}$ & $\mathrm{A}$ & $x$ & $x$ & $\mathrm{~A}$ & $\mathrm{O}$ & $x$ \\
\hline 2 & $\mathrm{O}$ & $\mathrm{O}$ & $\mathrm{O}$ & $\mathrm{O}$ & $\mathrm{O}$ & $\mathrm{O}$ & $\mathrm{O}$ & A & $\mathrm{O}$ & $\mathrm{O}$ & A & $\mathrm{O}$ & A & $\mathrm{O}$ & $\mathrm{O}$ & $\mathrm{O}$ & $\mathrm{O}$ & $X$ & \\
\hline 3 & $\mathrm{~V}$ & $\mathrm{~V}$ & $\mathrm{O}$ & A & $\mathrm{V}$ & $\mathrm{A}$ & $\mathrm{A}$ & $\mathrm{V}$ & $\mathrm{V}$ & $\mathrm{V}$ & $\mathrm{V}$ & $X$ & $\mathrm{O}$ & $\mathrm{O}$ & $\mathrm{V}$ & $\mathrm{V}$ & $x$ & & \\
\hline 4 & $\mathrm{~V}$ & $\mathrm{~V}$ & $\mathrm{O}$ & A & $X$ & $\mathrm{~A}$ & $\mathrm{~A}$ & $\mathrm{~V}$ & $\mathrm{~V}$ & $\mathrm{~V}$ & $x$ & $X$ & $\mathrm{~V}$ & $\mathrm{~A}$ & $x$ & $X$ & & & \\
\hline 5 & $\mathrm{~V}$ & $\mathrm{~V}$ & $\mathrm{O}$ & A & $\mathrm{V}$ & $\mathrm{A}$ & $\mathrm{A}$ & $\mathrm{V}$ & $\mathrm{V}$ & $\mathrm{V}$ & $\mathrm{V}$ & $X$ & A & $X$ & $x$ & & & & \\
\hline 6 & $\mathrm{~V}$ & $\mathrm{~V}$ & $\mathrm{O}$ & A & $X$ & $\mathrm{~A}$ & $\mathrm{~A}$ & $\mathrm{~V}$ & $\mathrm{~V}$ & $\mathrm{~V}$ & $\mathrm{~V}$ & $\mathrm{~V}$ & $\mathrm{~V}$ & $x$ & & & & & \\
\hline 7 & $\mathrm{~V}$ & $\mathrm{~V}$ & $\mathrm{O}$ & A & $\mathrm{V}$ & $\mathrm{A}$ & $\mathrm{A}$ & $\mathrm{V}$ & $\mathrm{V}$ & $\mathrm{V}$ & $\mathrm{V}$ & $\mathrm{V}$ & $\mathrm{V}$ & & & & & & \\
\hline 8 & $x$ & $\mathrm{~V}$ & $\mathrm{O}$ & A & $\mathrm{O}$ & $\mathrm{A}$ & $\mathrm{A}$ & $\mathrm{V}$ & $X$ & $\mathrm{~V}$ & $\mathrm{~V}$ & $x$ & & & & & & & \\
\hline 9 & $x$ & $\mathrm{~V}$ & $\mathrm{O}$ & A & $\mathrm{O}$ & $\mathrm{A}$ & $\mathrm{A}$ & $\mathrm{V}$ & $\mathrm{A}$ & A & $x$ & & & & & & & & \\
\hline 10 & $\mathrm{~V}$ & $\mathrm{~V}$ & $\mathrm{O}$ & A & $\mathrm{O}$ & $\mathrm{A}$ & $\mathrm{A}$ & $\mathrm{V}$ & $\mathrm{A}$ & $x$ & & & & & & & & & \\
\hline 11 & $\mathrm{~V}$ & $\mathrm{~V}$ & $\mathrm{O}$ & A & $X$ & $\mathrm{~A}$ & $\mathrm{~A}$ & $\mathrm{~V}$ & $X$ & & & & & & & & & & \\
\hline 12 & $x$ & $\mathrm{~V}$ & $\mathrm{O}$ & A & $\mathrm{V}$ & $\mathrm{A}$ & $\mathrm{A}$ & $x$ & & & & & & & & & & & \\
\hline 13 & $\mathrm{~V}$ & $\mathrm{O}$ & $\mathrm{O}$ & $\mathrm{O}$ & $\mathrm{O}$ & $\mathrm{V}$ & $X$ & & & & & & & & & & & & \\
\hline 14 & $\mathrm{~V}$ & $\mathrm{O}$ & $\mathrm{O}$ & A & $\mathrm{O}$ & $x$ & & & & & & & & & & & & & \\
\hline 15 & $x$ & $\mathrm{O}$ & $\mathrm{O}$ & A & $X$ & & & & & & & & & & & & & & \\
\hline 16 & $\mathrm{~V}$ & $\mathrm{~V}$ & $\mathrm{O}$ & $x$ & & & & & & & & & & & & & & & \\
\hline 17 & $\mathrm{O}$ & $\mathrm{O}$ & $X$ & & & & & & & & & & & & & & & & \\
\hline 18 & A & $x$ & & & & & & & & & & & & & & & & & \\
\hline 19 & $X$ & & & & & & & & & & & & & & & & & & \\
\hline
\end{tabular}

\subsection{Building the Reachability Matrix (RM)}

Following the ISM analysis procedure, an initial reachability matrix was developed from the SSIM above and the information of each cell of SSIM was converted into binary digits, 1 or 0 . The transformation was done with the following rules:

(1) The cell $(i, j)$ of the SSIM containing a " $V$ " should be filled with 1 and the corresponding cell $(j, i)$ should be filled with 0 .

(2) The cell $(i, j)$ of the SSIM containing a " $A$ " should be filled with 0 and the corresponding cell $(j, i)$ should be filled with 1 .

(3) The cell $(i, j)$ of the SSIM containing a " $X$ " should be filled with 1 and the corresponding cell $(j, i)$ should be filled with 1 .

(4) The cell $(\mathrm{i}, \mathrm{j})$ of the SSIM containing a " $\mathrm{O}$ " should be filled with 0 and the corresponding cell $(j, i)$ should be filled with 0 . 
The initial reachability matrix is given in Table 3.

Table 3. Initial reachability matrix.

\begin{tabular}{ccccccccccccccccccccc}
\hline $\begin{array}{c}\text { Influencing } \\
\text { Factors }\end{array}$ & $\mathbf{1}$ & $\mathbf{2}$ & $\mathbf{3}$ & $\mathbf{4}$ & $\mathbf{5}$ & $\mathbf{6}$ & $\mathbf{7}$ & $\mathbf{8}$ & $\mathbf{9}$ & $\mathbf{1 0}$ & $\mathbf{1 1}$ & $\mathbf{1 2}$ & $\mathbf{1 3}$ & $\mathbf{1 4}$ & $\mathbf{1 5}$ & $\mathbf{1 6}$ & $\mathbf{1 7}$ & $\mathbf{1 8}$ & $\mathbf{1 9}$ \\
\hline 1 & 1 & 0 & 0 & 1 & 1 & 0 & 0 & 0 & 1 & 0 & 1 & 0 & 0 & 0 & 0 & 0 & 0 & 1 & 1 \\
2 & 0 & 1 & 0 & 0 & 0 & 0 & 0 & 0 & 0 & 0 & 0 & 0 & 0 & 0 & 0 & 0 & 0 & 0 & 0 \\
3 & 1 & 0 & 1 & 1 & 1 & 0 & 0 & 1 & 1 & 1 & 1 & 1 & 0 & 0 & 1 & 0 & 0 & 1 & 1 \\
4 & 1 & 0 & 0 & 1 & 1 & 0 & 1 & 1 & 1 & 1 & 1 & 1 & 0 & 0 & 1 & 0 & 0 & 1 & 1 \\
5 & 1 & 0 & 0 & 1 & 1 & 1 & 0 & 1 & 1 & 1 & 1 & 1 & 0 & 0 & 1 & 0 & 0 & 1 & 1 \\
6 & 1 & 0 & 0 & 1 & 1 & 1 & 1 & 1 & 1 & 1 & 1 & 1 & 0 & 0 & 1 & 0 & 0 & 1 & 1 \\
7 & 0 & 1 & 0 & 0 & 1 & 0 & 1 & 1 & 1 & 1 & 1 & 1 & 0 & 0 & 1 & 0 & 0 & 1 & 1 \\
8 & 1 & 0 & 1 & 1 & 1 & 0 & 0 & 1 & 1 & 1 & 1 & 1 & 0 & 0 & 0 & 0 & 0 & 1 & 1 \\
9 & 1 & 1 & 0 & 1 & 0 & 0 & 0 & 0 & 1 & 0 & 0 & 1 & 0 & 0 & 0 & 0 & 0 & 1 & 1 \\
10 & 0 & 0 & 0 & 0 & 0 & 0 & 0 & 0 & 1 & 1 & 0 & 1 & 0 & 0 & 0 & 0 & 0 & 1 & 1 \\
11 & 1 & 0 & 0 & 0 & 0 & 0 & 0 & 1 & 1 & 1 & 1 & 1 & 0 & 0 & 1 & 0 & 0 & 1 & 1 \\
12 & 1 & 1 & 0 & 0 & 0 & 0 & 0 & 0 & 0 & 0 & 0 & 1 & 0 & 0 & 1 & 0 & 0 & 1 & 1 \\
13 & 1 & 0 & 1 & 1 & 1 & 1 & 1 & 1 & 1 & 1 & 1 & 1 & 1 & 1 & 0 & 0 & 0 & 0 & 1 \\
14 & 1 & 0 & 1 & 1 & 1 & 1 & 1 & 1 & 1 & 1 & 1 & 1 & 0 & 1 & 0 & 0 & 0 & 0 & 1 \\
15 & 1 & 0 & 0 & 1 & 0 & 1 & 0 & 0 & 0 & 0 & 1 & 0 & 0 & 0 & 1 & 0 & 0 & 0 & 1 \\
16 & 1 & 0 & 1 & 1 & 1 & 1 & 1 & 1 & 1 & 1 & 1 & 1 & 0 & 1 & 1 & 1 & 0 & 1 & 1 \\
17 & 0 & 0 & 0 & 0 & 0 & 0 & 0 & 0 & 0 & 0 & 0 & 0 & 0 & 0 & 0 & 0 & 1 & 0 & 0 \\
18 & 0 & 0 & 0 & 0 & 0 & 0 & 0 & 0 & 0 & 0 & 0 & 0 & 0 & 0 & 0 & 0 & 0 & 1 & 0 \\
19 & 0 & 0 & 0 & 0 & 0 & 0 & 0 & 1 & 1 & 0 & 0 & 1 & 0 & 0 & 1 & 0 & 0 & 1 & 1 \\
\hline
\end{tabular}

According to the ISM methodology, the final reachability matrix of the influencing factors is obtained by incorporating the transitivities from the enumeration of Table 3 and shown in Table 4.

Table 4. Final reachability matrix.

\begin{tabular}{|c|c|c|c|c|c|c|c|c|c|c|c|c|c|c|c|c|c|c|c|c|}
\hline $\begin{array}{l}\text { Influencing } \\
\text { Factors }\end{array}$ & 1 & 2 & 3 & 4 & 5 & 6 & 7 & 8 & 9 & 10 & 11 & 12 & 13 & 14 & 15 & 16 & 17 & 18 & 19 & $\begin{array}{l}\text { Driving } \\
\text { Power }\end{array}$ \\
\hline 1 & 1 & 1 & 1 & 1 & 1 & 1 & 1 & 1 & 1 & 1 & 1 & 1 & 0 & 0 & 1 & 0 & 0 & 1 & 1 & 15 \\
\hline 2 & 0 & 1 & 0 & 0 & 0 & 0 & 0 & 0 & 0 & 0 & 0 & 0 & 0 & 0 & 0 & 0 & 0 & 0 & 0 & 1 \\
\hline 3 & 1 & 1 & 1 & 1 & 1 & 1 & 1 & 1 & 1 & 1 & 1 & 1 & 0 & 0 & 1 & 0 & 0 & 1 & 1 & 15 \\
\hline 4 & 1 & 1 & 1 & 1 & 1 & 1 & 1 & 1 & 1 & 1 & 1 & 1 & 0 & 0 & 1 & 0 & 0 & 1 & 1 & 15 \\
\hline 5 & 1 & 1 & 1 & 1 & 1 & 1 & 1 & 1 & 1 & 1 & 1 & 1 & 0 & 0 & 1 & 0 & 0 & 1 & 1 & 15 \\
\hline 6 & 1 & 1 & 1 & 1 & 1 & 1 & 1 & 1 & 1 & 1 & 1 & 1 & 0 & 0 & 1 & 0 & 0 & 1 & 1 & 15 \\
\hline 7 & 1 & 1 & 1 & 1 & 1 & 1 & 1 & 1 & 1 & 1 & 1 & 1 & 0 & 0 & 1 & 0 & 0 & 1 & 1 & 15 \\
\hline 8 & 1 & 1 & 1 & 1 & 1 & 1 & 1 & 1 & 1 & 1 & 1 & 1 & 0 & 0 & 1 & 0 & 0 & 1 & 1 & 15 \\
\hline 9 & 1 & 1 & 1 & 1 & 1 & 1 & 1 & 1 & 1 & 1 & 1 & 1 & 0 & 0 & 1 & 0 & 0 & 1 & 1 & 15 \\
\hline 10 & 1 & 1 & 1 & 1 & 1 & 1 & 1 & 1 & 1 & 1 & 1 & 1 & 0 & 0 & 1 & 0 & 0 & 1 & 1 & 15 \\
\hline 11 & 1 & 1 & 1 & 1 & 1 & 1 & 1 & 1 & 1 & 1 & 1 & 1 & 0 & 0 & 1 & 0 & 0 & 1 & 1 & 15 \\
\hline 12 & 1 & 1 & 1 & 1 & 1 & 1 & 1 & 1 & 1 & 1 & 1 & 1 & 0 & 0 & 1 & 0 & 0 & 1 & 1 & 15 \\
\hline 13 & 1 & 1 & 1 & 1 & 1 & 1 & 1 & 1 & 1 & 1 & 1 & 1 & 1 & 1 & 1 & 0 & 0 & 1 & 1 & 17 \\
\hline 14 & 1 & 1 & 1 & 1 & 1 & 1 & 1 & 1 & 1 & 1 & 1 & 1 & 0 & 1 & 1 & 0 & 0 & 1 & 1 & 16 \\
\hline 15 & 1 & 1 & 1 & 1 & 1 & 1 & 1 & 1 & 1 & 1 & 1 & 1 & 0 & 0 & 1 & 0 & 0 & 1 & 1 & 15 \\
\hline 16 & 1 & 1 & 1 & 1 & 1 & 1 & 1 & 1 & 1 & 1 & 1 & 1 & 0 & 1 & 1 & 1 & 0 & 1 & 1 & 17 \\
\hline 17 & 0 & 0 & 0 & 0 & 0 & 0 & 0 & 0 & 0 & 0 & 0 & 0 & 0 & 0 & 0 & 0 & 1 & 0 & 0 & 1 \\
\hline 18 & 0 & 0 & 0 & 0 & 0 & 0 & 0 & 0 & 0 & 0 & 0 & 0 & 0 & 0 & 0 & 0 & 0 & 1 & 0 & 1 \\
\hline 19 & 1 & 1 & 1 & 1 & 1 & 1 & 1 & 1 & 1 & 1 & 1 & 1 & 0 & 0 & 1 & 0 & 0 & 1 & 1 & 15 \\
\hline $\begin{array}{l}\text { Dependent } \\
\text { power }\end{array}$ & 16 & 17 & 16 & 16 & 16 & 16 & 16 & 16 & 16 & 16 & 16 & 16 & 1 & 3 & 16 & 1 & 1 & 17 & 16 & \\
\hline
\end{tabular}

Table 4 also includes the driving and dependence powers of each factor. The driving power is the total number of factors (including itself) that a specific factor may help to achieve; while the dependent power is the total number of factors (including itself) that may help to achieve the specific factor. With the final reachability matrix, both the driving and dependence powers are counted. The driving power of a factor is equal to the sum of 
the numbers in the line of the factor and its dependence power is equal to the sum of the numbers in the column.

\subsection{Levels Partitioning and Development of ISM-Based Model}

Using the final reachability matrix, the reachability and antecedent set for each factor is obtained, the intersection of these two sets is derived as well for all the factors. The factors for which the reachability and the intersection sets are the same occupy the top level in the ISM hierarchy, which would not help to achieve any other factor above its own level. After the top-level factors are identified, they are discarded from the other remaining variables. Then the rest of the factors construct the new reachability and intersection sets for examination. Influencing factors for which the intersection and the reachability sets were identical were to be considered as pertaining to level 2 and were then eliminated from the table. The procedure was repeated until all the factors were categorized in levels. The reachability, antecedents and intersection sets, along with the calculated level for each one of the factors are presented in Table 5.

Table 5. Level partitioning factors.

\begin{tabular}{|c|c|c|c|c|}
\hline $\begin{array}{l}\text { Influencing } \\
\text { Factors }\end{array}$ & Reachability Set & Antecedent Set & Intersection Set & Level \\
\hline 1 & $1,2,3,4,5,6,7,8,9,10,11,12,15,18,19$ & $1,3,4,5,6,7,8,9,10,11,12,13,14,15,16,19$ & $1,3,4,5,6,7,8,9,10,11,12,15,19$ & 2 \\
\hline 2 & 2 & $1,2,3,3,4,5,6,7,8,9,10,11,12,13,14,15,16,19$ & 2 & 1 \\
\hline 3 & $1,2,3,4,5,6,7,8,9,10,11,12,15,18,19$ & $1,3,4,5,6,7,8,9,10,11,12,13,14,15,16,19$ & $1,3,4,5,6,7,8,9,10,11,12,15,19$ & 2 \\
\hline 4 & $1,2,3,4,5,6,7,8,9,10,11,12,15,18,19$ & $1,3,4,5,6,7,8,9,10,11,12,13,14,15,16,19$ & $1,3,4,5,6,7,8,9,10,11,12,15,19$ & 2 \\
\hline 5 & $1,2,3,4,5,6,7,8,9,10,11,12,15,18,19$ & $1,3,4,5,6,7,8,9,10,11,12,13,14,15,16,19$ & $1,3,4,5,6,7,8,9,10,11,12,15,19$ & 2 \\
\hline 6 & $1,2,3,4,5,6,7,8,9,10,11,12,15,18,19$ & $1,3,4,5,6,7,8,9,10,11,12,13,14,15,16,19$ & $1,3,4,5,6,7,8,9,10,11,12,15,19$ & 2 \\
\hline 7 & $1,2,3,4,5,6,7,8,9,10,11,12,15,18,19$ & $1,3,4,5,6,7,8,9,10,11,12,13,14,15,16,19$ & $1,3,4,5,6,7,8,9,10,11,12,15,19$ & 2 \\
\hline 8 & $1,2,3,4,5,6,7,8,9,10,11,12,15,18,19$ & $1,3,4,5,6,7,8,9,10,11,12,13,14,15,16,19$ & $1,3,4,5,6,7,8,9,10,11,12,15,19$ & 2 \\
\hline 9 & $1,2,3,4,5,6,7,8,9,10,11,12,15,18,19$ & $1,3,4,5,6,7,8,9,10,11,12,13,14,15,16,19$ & $1,3,4,5,6,7,8,9,10,11,12,15,19$ & 2 \\
\hline 10 & $1,2,3,4,5,6,7,8,9,10,11,12,15,18,19$ & $1,3,4,5,6,7,8,9,10,11,12,13,14,15,16,19$ & $1,3,4,5,6,7,8,9,10,11,12,15,19$ & 2 \\
\hline 11 & $1,2,3,4,5,6,7,8,9,10,11,12,15,18,19$ & $1,3,4,5,6,7,8,9,10,11,12,13,14,15,16,19$ & $1,3,4,5,6,7,8,9,10,11,12,15,19$ & 2 \\
\hline 12 & $1,2,3,4,5,6,7,8,9,10,11,12,15,18,19$ & $1,3,4,5,6,7,8,9,10,11,12,13,14,15,16,19$ & $1,3,4,5,6,7,8,9,10,11,12,15,19$ & 2 \\
\hline 13 & $1,2,3,4,5,6,7,8,9,10,11,12,13,14,15,18,19$ & 13 & 13 & 4 \\
\hline 14 & $1,2,3,4,5,6,7,8,9,10,11,12,14,15,18,19$ & $13,14,16$ & 14 & 3 \\
\hline 15 & $1,2,3,4,5,6,7,8,9,10,11,12,15,18,19$ & $1,3,4,5,6,7,8,9,10,11,12,13,14,15,16,19$ & $1,3,4,5,6,7,8,9,10,11,12,15,19$ & 2 \\
\hline 16 & $1,2,3,4,5,6,7,8,9,10,11,12,14,15,16,18,19$ & 16 & 16 & 4 \\
\hline 17 & 17 & 17 & 17 & 1 \\
\hline 18 & 18 & $1,3,4,5,6,7,8,9,10,11,12,13,14,15,16,18,19$ & 18 & 1 \\
\hline 19 & $1,2,3,4,5,6,7,8,9,10,11,12,15,18,19$ & $1,3,4,5,6,7,8,9,10,11,12,13,14,15,16,19$ & $1,3,4,5,6,7,8,9,10,11,12,15,19$ & 2 \\
\hline
\end{tabular}

Based on the results of level partitioning, the hierarchical structural model is generated. The relationship between the factors $i$ and $j$, is represented by an arrow pointing from $i$ to $\mathrm{j}$. Then the transitivity is removed as described in the ISM methodology and the final digraph is converted into the ISM-based model as shown in Figure 1.

\subsection{MICMAC Analysis}

MICMAC referring to Matriced Impacts croises-multipication appliqueand classment (cross-impact matrix multiplication applied to classification), is based on multiplication properties of matrices. The final reachability matrix is also used to conduct a MICMAC analysis with both the driving and dependence powers, as shown in Table 4. MICMAC analysis tries to explain the driving power and dependence power of factors and it is conducted to identify the key factors that drive the system in various categories. Based on the driving and dependence power, the factors can be classified into four categories, including autonomous, dependent, linkage, and independent factors; which are represented graphically in a two-dimension chart of Figure 2.

Autonomous factors are those that have weak driving power and weak dependence. They are relatively detached from the system and either strongly enhance or inhibit the influence of other factors. Additionally, they are situated in the lower-left frame of the chart of Quadrant I. Out of the 19 identified influencing factors, only factor 17 pertain to this category. 


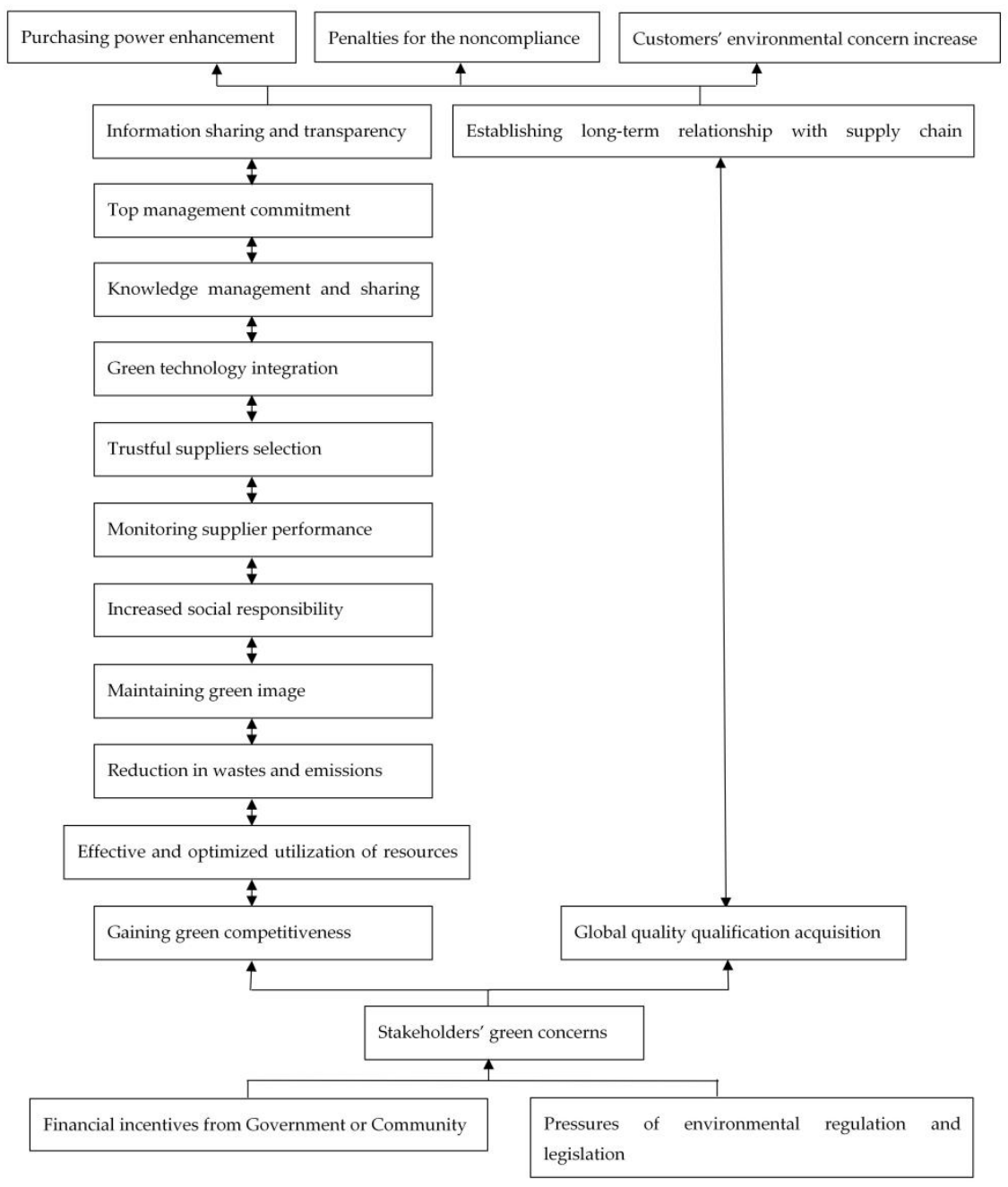

Figure 1. ISM based model for influencing factors.

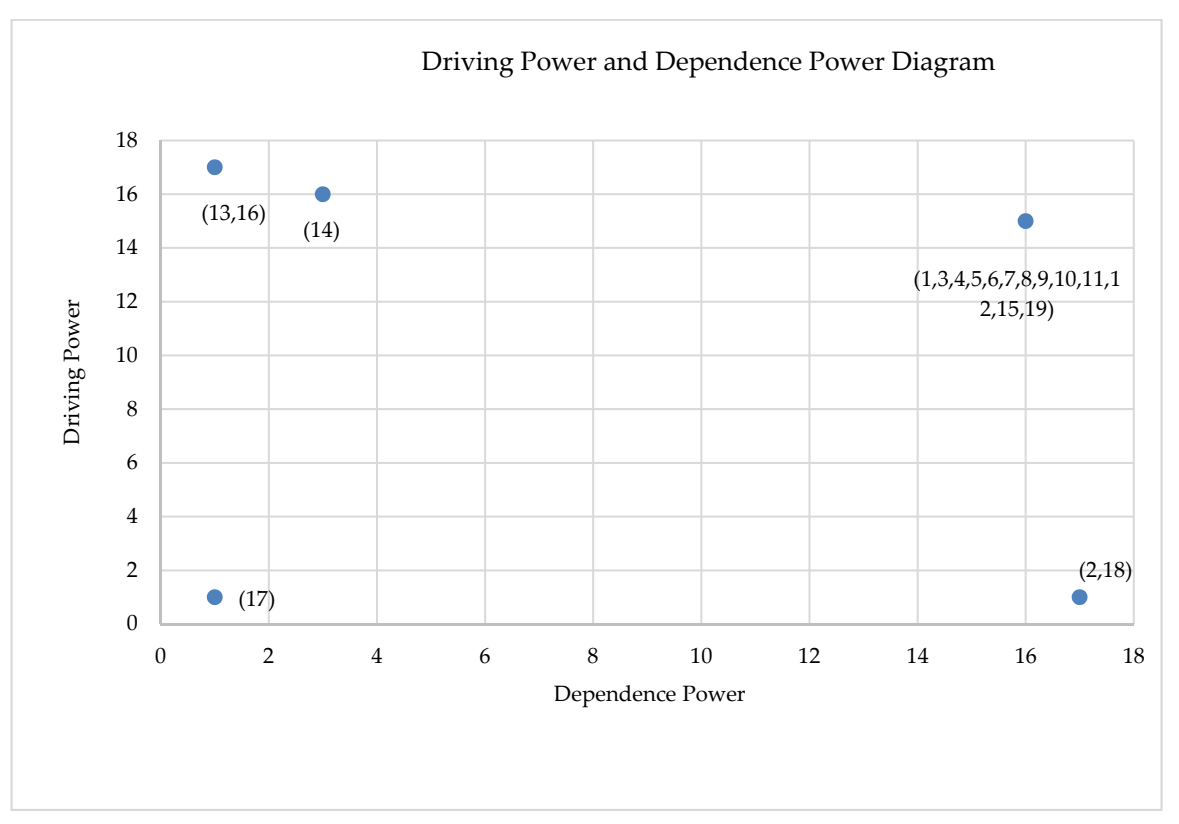

Figure 2. Driving power and dependence power diagram. 
Dependent factors are the ones which have weak driving power but strong dependence power and are highly conditioned by the effect of the independent and linkage factors. The dependent factors are place in Quadrant II which is the lower-right frame of the chart and two factors in this study pertain to this category; they are factors 2 and 18.

Linkage factors are the ones located in the upper-right frame of the chart, Quadrant III. They have both high influence power and high dependent power. The effect or action of the inflowing factors that pass through the linkage factors will be amplified or obstructed depending on the value of those linkage factors. In this model, 12 factors pertaining to this category are factors $1,3-12,15$, and 19.

Independent factors are represented in Quadrant IV which is the upper-left frame of the chart. These are the factors of high driving and low dependence power, which are the key to understanding the attribute of the system as most of the other factors within the system are depending on them. This category contains three factors in this examination and they are factors 13,14, and 16.

\section{Results and Discussion}

Much attention has been paid to the importance of green supply chain development, which is expected to effectively create a win-win relationship between environmental performance and economic efficiency throughout the supply chain. Development of green supply chain management among manufacturers in China is rapid but still some gaps like green supply chain cooperation affect their performance. Environmental improvements are essential for Chinese industries as an increasing number of enterprises has been involved in the global supply chain. The members within the supply chain have worked together to reduce pollution and other environmental impacts through inter-organizational interactions. Greening the supply chain is not an easy task indeed and it is the cooperation that is vital for all the partners through the chain to achieve positive environmental performance; while there exists a number of factors for the manufacturers to cooperate with each other. This paper extracts the influential factors that promote green supply chain cooperation from the literature, consults industry experts and scholars, and uses ISM to explain the interaction between these factors. The analysis on the factors can help the supply chain partners for better cooperation and further for improved environmental outcomes. The driving and dependence power diagram obtained from MICMAC analysis provides an insight into the relative importance and inter-dependencies between these factors. Some of the important findings of this study will be underlined.

1. There is only one autonomous factor (factor 17). Autonomous factors are weak factors and weak dependents, thus have little influence on the system. Only one autonomous factor signifies at least two points; firstly, most of the considered factors in this study play a significant role and secondly the penalties for the noncompliance has not had much effect on the process of the green supply chain cooperation among manufacturers in China. Thus, Chinese manufacturers were not affected by punishment or penalty when they would like to coordinate with their supply chain partners in terms of green actions or environmental issues.

2. Dependent factors are Customers' environmental concern increase (factor 2) and Purchasing power enhancement (factor 18). They are weak factors but strongly dependent on one another. Due to the encouragement or pressures from the government in terms of environmental issues, the manufacturers would like to take actions in their purchasing strategy towards suppliers for green purchases; thus, this factor also has a weak drive power (1) and strong dependence power (17). Due to the increasing concern about environmental issues among stakeholders which encourages the cooperation between supply chain partners, consumers become aware of environmental protection and energy saving; so, it is why customers' environmental concern increase has a weak drive power (1) and strong dependence power (17). While the stakeholders' environmental concern could rise on account of the rising of government's environmental responsibility. This reveals that manufacturers paid little attention to their enhancement of purchasing power when 
cooperating across the supply chain and the increase of customers' environmental concern was not a strong contributor to promote the green supply chain cooperation. Moreover, the government regulations on environment should be implemented in a stricter manner in China for reinforcing the green cooperation among manufactures.

3. Thirteen factors fall in the linkage factor in Quadrant III of the diagram which can be classified into two main categories, that is CSR motivations and external stakeholder drivers. Such classification is based on the fact that green supply chain cooperation has both inherent feasibility and external necessity. In CSR category there are 11 factors, including Information sharing and transparency (factor 1), Top management commitment (factor 3), Knowledge management and sharing (factor 4), Green technology integration (factor 5), Trustful suppliers selection (factor 6), Monitoring supplier performance (factor 7), Increased social responsibility (factor 8), Maintaining green image (factor 9), Reduction in wastes and emissions (factor 10), Effective and optimized utilization of resources and energy (factor 11), and Gaining green competitiveness (factor 12); whereas, the external stakeholder concerns consist of Establishing long-term relationship with supply chain partners (factor 15) and Global quality qualification acquisition (factor 19). Additionally, all the 13 factors have driving power of 17 and dependence power of 16. It is in line with Freeman's point of view, stakeholders arise from both internal and external sources to the enterprises [88].

CSR refers to internal stakeholders of the enterprise, including owners, employees and internal customers and suppliers, while external stakeholders refer to governments, competitors, consumer advocates, environmentalists, special interest groups, media, etc. They originate from the ambiguous area of "environment" and influence the ability of enterprises to respond to internal changes. The motivations from employees and managerial stakeholders to proactively implement environmental management practices can create a virtuous cycle which leads to additional influencing factors from internal stakeholders. According to Reinhardt, if there is a prevalence of environmental concerns throughout an enterprise, it is more likely to recruit talented applicants who have a strong preference to work in enterprises with proactive environmental management philosophies [89]. Those factors from insiders of any partner enterprise across the supply chain would convert into the motivation of cooperation for greening the supply chain.

External stakeholders of customers and suppliers can affect the implementation of environmental practices within a manufacturing enterprise; especially those stakeholders who require their suppliers to adhere to certain practices for the improvement of their environmental performance [11,90]. For instance, downstream partners tend to ask for their suppliers to provide documentary evidence of their compliance with all environmental regulations, such as ISO 14,000 [91]. Factors originate from downwards because they like to ensure that their purchases meet environmental quality standards and, by doing so, reduce environmental liabilities associated with final product development [92].

Three factors are the independent factors given in Quadrant IV. They are Stakeholders' green concerns (factor 14) with a driving power (16) and a dependent power (3), Financial incentives from government or community (factor 13) and Pressures of environmental regulation and legislation (factor 16), both of which have a strong driving power of 17 and a very weak dependent power of 1 . Thus, they can be viewed as the key factors. As discussed before, stakeholders' green concerns have obvious driving power to the internal and external factors for Chinese manufacturers to cooperate with their suppliers for a green supply chain. Furthermore, regulatory parties and government are the most significant external stakeholders when it comes to environmental issues [88,93], and are typically associated with coercive pressures [94]; thus, they have the most vital driving power in the factor system. Enterprises must comply with environmental regulations, to enjoy the encouragement, especially for financial incentives or face the threat of regulators levying legal action, penalties and fines. Failure to yield to environmental regulatory will damage the enterprise's public image and customer relations. Enterprises can conduct organizational training of proactive environmental practices as one means by which to alleviate these regulatory threats and risks. In fact, proactive environmental practices can help enter- 
prises form collaborative relationships with government to explore more nonregulatory approaches, where government can encourage greater environmental improvements [95] and provide more opportunities to build trust between manufacturers and regulators [96].

\section{Conclusions}

Facing an increasingly competitive market, in order to achieve the balance of cost reduction, economic growth and environmental friendship, a number of enterprises have established networks of their suppliers to increase their competitiveness. Manufacturing enterprises in China play an important role in the provincial economy and are willing to cooperate with their supply chain partners for the purpose of improving environmental performance. The influencing factors hindering the cooperation need to be identified to further arouse the copartnership between Chinese manufacturers to achieve greener supply chains. Factors that stemmed from CSR and external stakeholders have been identified and analyzed in terms of the interaction among them by using ISM. With the feedback from supply chain management practitioners of manufacturers and academicians of universities in China, a structural self-interaction matrix (SSIM) was formed as the basis for the interpretive structural modeling (ISM); these identified influencing factors are iterated in four levels.

A structural model was formed using ISM, where the Purchasing power enhancement (factor 2), Penalties for the noncompliance (factor 17) and Customers' environmental concern increase (factor 18) occupied the top level. These factors are impacted at the lower level and they are also those factors that put less effect as compared to the remaining factors. It indicates that the manufacturers in China feel that the three factors give them the least driving power to cooperate with their suppliers to achieve a green supply chain. In the second level, there are 13 factors including Information sharing and transparency (factor 1), Top management commitment (factor 3), Knowledge management and sharing (factor 4), Green technology integration (factor 5), Trustful suppliers selection (factor 6), Monitoring supplier performance (factor 7), Increased social responsibility (factor 8), Maintaining green image (factor 9), Reduction in wastes and emissions (factor 10), Effective and optimized utilization of resources and energy (factor 11), Gaining green competitiveness (factor 12), Establishing long-term relationship with supply chain partners (factor 15), and Global quality qualification acquisition (factor 19). It shows that these 13 factors could give equal impact for green supply chain cooperation. The influencing factors from CSR and external stakeholder concerns should be paid attention to simultaneously to strengthen the cooperation between suppliers. Only one factor of Stakeholders' green concerns (factor 14) is placed in level three. Additionally this is a strong motivator that would have an influence up to the factors in level one and level two, which implies that the increasing environmental concern from stakeholders of manufacturers in China positively influences their green supply chain cooperation. Financial incentives from government or community (factor 13) and Pressures of environmental regulation and legislation (factor 16) occupied the bottom most level of the system. These two factors act as vital factors for cooperating with supply chain partners to achieve better environmental performances. They are driving the remaining factors but are not very dependent on other factors. This finding is also consistent with many other studies showing that government regulatory pressure and incentives as drivers of external stakeholders have a positive impact on green supply chain management in manufacturing industry. Thus, they might be the major factors for cooperation for greening the supply chain.

With the diagnosis of the major influencing factors of green supply chain cooperation, it becomes clear how the manufacturers can be motivated to implement environmental cooperation strategies through their supply chains. It will further lead to the manufacturing of eco-friendly products and the ability to sustain in the market is also increased for the manufacturers. This study suggests that Financial incentives from government or community and Pressures of environmental regulation and legislation are acting as the significant factors for the green supply chain cooperation. Regulatory parties need 
to give attention to both incentive and coercive impetus towards the manufacturers to drive their cooperation for improved environmental performances. Then the virtuous circle of cooperation is moving, in that the manufacturers will be very keen in selecting suppliers with consideration of green concepts and adopting eco-friendly materials from their suppliers. The overall green perspective will also help to generate environmentally friendly products in the end and the product image as well as the enterprise image will be improved in the market and public as an eco-friendly manufacturer. It will also be good to obtain government rewards or awards for such cooperation.

ISM approach was implied with 19 influencing factors from CSR and external stakeholder concerns for the green supply chain cooperation only in the manufacturing enterprises in China in this study. More factors could have not been considered and not classified. Future scope of this study should be widened to identify the essential factors in other Chinese industries for green supply chain cooperation from the perspectives like multicriteria decision making techniques.

Author Contributions: X.H. and S.Y. conceived and designed the study; X.H. performed the calculation; X.H. and S.Y. analyzed the data; X.S. contributed analysis tools; X.H., S.Y. and X.S. wrote the paper. All authors have read and agreed to the published version of the manuscript.

Funding: The research was funded by National Natural Science Foundation of China [Grant No. 71901042]. The research was also funded by the Philosophy and Social Science Research of Jiangsu Higher Education Institutions of China [Grant No. 2018SJZDI044].

Institutional Review Board Statement: Not applicable.

Informed Consent Statement: Not applicable.

Data Availability Statement: Not applicable.

Acknowledgments: The authors are grateful to the editors and anonymous reviewers for providing the valuable comments.

Conflicts of Interest: The authors declare no conflict of interest. The founding sponsors had no role in the design of the study; in the collection, analyses, or interpretation of data; in the writing of the manuscript, and in the decision to publish the results.

\section{References}

1. MEEC (Ministry of Ecology and Environment of China). China's Ecological and Environmental Statements 2018; MEEC: Beijing, China, 2019.

2. Ramanathan, U.; Bentley, Y.; Pang, G. The role of collaboration in the UK green supply chains: An exploratory study of the perspectives of suppliers, logistics and retailers. J. Clean. Prod. 2014, 70, 231-241. [CrossRef]

3. Swami, S.; Shah, J. Channel coordination in green supply chain management. J. Oper. Res. Soc. 2013, 64, 336-351. [CrossRef]

4. Mentzer, J.T.; Dewitt, W.; Keebler, J.S. Defining supply chain management. J. Bus. Logist. 2001, 22, 1-25. [CrossRef]

5. Srivastava, S.K. Green supply-chain management: A state-of-the-art literature review. Int. J. Manag. Rev. 2007, 9, 53-80. [CrossRef]

6. Hart, S.L. A natural-resource-based view of the firm. Acad. Manag. Rev. 1995, 20, 986-1014. [CrossRef]

7. Zhu, Q.; Geng, Y. Drivers and barriers of extended supply chain practices for energy saving and emission reduction among Chinese manufacturers. J. Clean. Prod. 2013, 40, 6-12. [CrossRef]

8. Singh, A.K.; Jha, S.K.; Prakash, A. Green Manufacturing (GM) performance measures: An empirical investigation from Indian MSMEs. Int. J. Res. Advent Technol. 2014, 2, 51-65.

9. Thurner, T.W.; Roud, V. Greening strategies in Russia's manufacturing_From compliance to opportunity. J. Clean. Prod. 2016, 162, 1607-1616. [CrossRef]

10. Rao, P. Greening of the supply chain: An empirical study for SMEs in the Philippine context. J. Asia Bus. Stud. 2007, 1, 55-66. [CrossRef]

11. Zhu, Q.; Sarkis, J. Relationships between operational practices and performance among early adopters of green supply chain management practices in Chinese manufacturing enterprises. J. Oper. Manag. 2004, 22, 265-289. [CrossRef]

12. Carroll, A.B.; Shabana, K.M. The business case for corporate social responsibility: A review of concepts, research and practice. Int. J. Manag. Rev. 2010, 12, 85-105. [CrossRef]

13. Seuring, S. Sustainability management beyond corporate boundaries. J. Clean. Prod. 2010, 18, 1118-1119. [CrossRef]

14. Lozano, R. Developing collaborative and sustainable organisations. J. Clean. Prod. 2008, 16, 499-509. [CrossRef]

15. Govindan, K.; Seuring, S.; Zhu, Q.; Garrido, A.S. Accelerating the transition towards sustainability dynamics into supply chain relationship management and governance structures. J. Clean. Prod. 2016, 112, 1813-1823. [CrossRef] 
16. Subramanian, R.; Gupta, S.; Talbot, B. Product design and supply chain coordination under extended producer responsibility. Prod. Oper. Manag. 2009, 18, 259-277. [CrossRef]

17. Xu, J.; Chen, Y.; Bai, Q. A two-echelon sustainable supply chain coordination under cap-and-trade regulation. J. Clean. Prod. 2016, 135, 42-56. [CrossRef]

18. Govindan, K.; Popiuc, M.N. Reverse supply chain coordination by revenue sharing contract: A case for the personal computers industry. Eur. J. Oper. Res. 2014, 233, 326-336. [CrossRef]

19. Oglethorpe, D. Optimising economic, environmental, and social objectives: A goal-programming approach in the food sector. Environ. Plan. A 2010, 42, 1239-1254. [CrossRef]

20. Guo, Y.; Yen, D.A.; Geng, R.; Azar, G. Drivers of green cooperation between Chinese manufacturers and their customers: An empirical analysis. Ind. Mark. Manage. 2021, 93, 137-146. [CrossRef]

21. Zhang, J.; Gou, Q.; Liang, L.; Huang, Z. Supply chain coordination through cooperative advertising with reference price effect. Omega 2013, 41, 345-353. [CrossRef]

22. Dai, R.; Zhang, J.; Tang, W. Cartelization or cost-sharing? Comparison of cooperation modes in a green supply chain. J. Clean. Prod. 2017, 156, 159-173. [CrossRef]

23. Burr, C.; Knauff, M.; Stepanova, A. On the prisoner's dilemma in R\&D with input spillovers and incentives for R\&D cooperation. Math. Soc. Sci. 2013, 66, 254-261.

24. Marini, M.A.; Petit, M.L.; Sestini, R. Strategic timing in R\&D agreements. Econ. Innov. New Technol. 2014, 23, $274-303$.

25. Riedel, R.; Mueller, E. Production management and supply chain management in a global context. Int. J. Manuf. Technol. Manag. 2009, 16, 300. [CrossRef]

26. Berry, D.; Towill, D.R.; Wadsley, N. Supply chain management in the electronics products industry. Int. J. Phys. Distrib. Logist. Manag. 1994, 24, 20-32. [CrossRef]

27. Welford, R. Globalisation, corporate social responsibility and human rights. Corp. Soc. Responsib. Environ. Manag. 2002, 9, 1-8. [CrossRef]

28. González-Benito, J.; González-Benito, Ó. The role of stakeholder pressure and managerial values in the implementation of environmental logistics practices. Int. J. Prod. Res. 2006, 44, 1353-1373. [CrossRef]

29. Locke, R.; Romis, M. Improving work conditions in a global supply chain. MIT Sloan Manag. Rev. 2007, 48, 54-62.

30. Collins, C.M.; Steg, L.; Koning, M.A.S. Customers' values, beliefs on sustainable corporate performance, and buying behavior. Psychol. Mark. 2010, 24, 555-577. [CrossRef]

31. Hong, Z.; Guo, X. Green product supply chain contracts considering environmental responsibilities. Omega 2018, 83, 155-166. [CrossRef]

32. Rao, P.; Holt, D. Do green supply chains lead to competitiveness and economic performance? Int. J. Oper. Prod. Manag. 2013, 25, 898-916. [CrossRef]

33. Hoek, V.; Remko, I. From reversed logistics to green supply chains. Supply Chain Manag. Int. J. 1999, 4, 129-135. [CrossRef]

34. Vachon, S.; Klassen, R.D. Extending green practices across the supply chain: The impact of upstream and downstream integration. Int. J. Oper. Prod. Manag. 2006, 26, 795-821. [CrossRef]

35. Walton, S.V.; Handfield, R.B.; Melnyk, S.A. The green supply chain: Integrating suppliers into environmental management processes. J. Supply Chain Manag. 2010, 34, 2-11. [CrossRef]

36. Barratt, M. Understanding the meaning of collaboration in the supply chain. Supply Chain Manag. Int. J. 2004, 9, 30-42. [CrossRef]

37. Danese, P. Designing CPFR collaborations: Insights from seven case studies. Int. J. Oper. Prod. Manag. 2007, 27, 181-204. [CrossRef]

38. Ramanathan, R.; He, Q.; Black, A.; Ghobadian, A.; Gallear, D. Environmental regulations, innovation and firm performance: A revisit of the Porter hypothesis. J. Clean. Prod. 2016, 155, 79-92. [CrossRef]

39. Khan, O.; Christopher, M.; Creazza, A. Aligning product design with the supply chain: A case study. Supply Chain Manag. Int. J. 2012, 17, 323-336. [CrossRef]

40. Hart, S.L.; Dowell, G.I. A natural-resource-based view of the firm: Fifteen years after. J. Manag. 2011, 37, 1464-1479.

41. Sarkis, J.; Zhu, Q.; Lai, K.H. An organizational theoretic review of green supply chain management literature. Int. J. Prod. Econ. 2011, 130, 1-15. [CrossRef]

42. Hervani, A.A.; Helms, M.M.; Sarkis, J. Performance measurement for green supply chain management. Benchmarking Int. J. 2005, 12, 330-353. [CrossRef]

43. Melville, N.P. Information systems innovation for environmental sustainability. Mis Q. 2010, 34, 1-21. [CrossRef]

44. Fawcett, S.E.; Wallin, C.; Allred, C.; Fawcett, A.M.; Magnan, G.M. Information technology as an enabler of supply chain collaboration: A dynamic-capabilities perspective. J. Supply Chain Manag. 2011, 47, 38-59. [CrossRef]

45. Cai, Z.; Huang, Q.; Liu, H.; Liang, L. The moderating role of information technology capability in the relationship between supply chain collaboration and organizational responsiveness. Int. J. Oper. Prod. Manag. 2016, 36, 1247-1271. [CrossRef]

46. Handfield, R.; Sroufe, R.; Walton, S. Integrating environmental management and supply chain strategies. Bus. Strategy Environ. 2010, 14, 1-19. [CrossRef]

47. Large, R.O.; Thomsen, C.G. Drivers of green supply management performance: Evidence from Germany. J. Purch. Supply Manag. 2011, 17, 176-184. [CrossRef] 
48. Walker, H.; Jones, N. Sustainable supply chain management across the UK private sector. Supply Chain Manag. Int. J. 2012, 17, 15-28. [CrossRef]

49. Bowen, F.E.; Cousins, P.D.; Lamming, R.C.; Farukt, A.C. The role of supply management capabilities in green supply. Prod. Oper. Manag. 2001, 10, 174-189. [CrossRef]

50. Pujari, D.; Peattie, K.; Wright, G. Organizational antecedents of environmental responsiveness in industrial new product development. Ind. Mark. Manag. 2004, 33, 381-391. [CrossRef]

51. Pagell, M.; Wu, Z. Building a more complete theory of sustainable supply chain management using case studies of 10 exemplars. J. Supply Chain Manag. 2010, 45, 37-56. [CrossRef]

52. Hofer, C.; Cantor, D.E.; Dai, J. The competitive determinants of a firm's environmental management activities: Evidence from US manufacturing industries. J. Oper. Manag. 2012, 30, 69-84. [CrossRef]

53. Rehman, M.A.; Seth, D.; Shrivastava, R.L. Impact of green manufacturing practices on organisational performance in Indian context: An empirical study. J. Clean. Prod. 2016, 137, 427-448. [CrossRef]

54. Zhu, Q.; Sarkis, J.; Geng, Y. Green supply chain management in China: Pressures, practices and performance. Int. J. Oper. Prod. Manag. 2004, 23, 449-468. [CrossRef]

55. Cheng, J.; Yeh, C.; Tu, C. Trust and knowledge sharing in green supply chains. Supply Chain Manag. Int. J. 2008, 13, 283-295. [CrossRef]

56. Gmelin, H.; Seuring, S. Determinants of a sustainable new product development. J. Clean. Prod. 2014, 69, 1-9. [CrossRef]

57. Lee, S.Y. The effects of green supply chain management on the supplier's performance through social capital accumulation. Supply Chain Manag. 2015, 20, 42-55. [CrossRef]

58. Hoejmose, S.; Brammer, S.; Millington, A. “Green" supply chain management: The role of trust and top management in B2B and B2C markets. Ind. Mark. Manag. 2012, 41, 609-620. [CrossRef]

59. Hartmann, J.; Germain, R. Understanding the relationships of integration capabilities, ecological product design, and manufacturing performance. J. Clean. Prod. 2015, 92, 196-205. [CrossRef]

60. Sharma, S. Managerial interpretations and organizational context as predictors of corporate choice of environmental strategy. Acad. Manag. J. 2000, 43, 681-697.

61. Seuring, S. Integrated chain management and supply chain management comparative analysis and illustrative cases. J. Clean. Prod. 2004, 12, 1059-1071. [CrossRef]

62. Mudgal, R.K.; Shankar, R.; Talib, P.; Raj, T. Modelling the barriers of green supply chain practices: An Indian perspective. Int. J. Logist. Syst. Manag. 2010, 7, 81. [CrossRef]

63. Claver, E.; López, M.D.; Molina, J.F.; Tari, A.A. Environmental management and firm performance: A case study. J. Environ. Manag. 2007, 84, 606-619. [CrossRef] [PubMed]

64. Shang, K.C.; Lu, C.S.; Li, S.R. A taxonomy of green supply chain management capability among electronics-related manufacturing firms in Taiwan. J. Environ. Manag. 2010, 91, 1218-1226. [CrossRef] [PubMed]

65. Gunasekaran, A.; Spalanzani, A. Sustainability of manufacturing and services: Investigations for research and applications. Int. J. Prod. Econ. 2012, 140, 35-47. [CrossRef]

66. Tseng, M.L.; Chiu, A.S.F. Evaluating firm's green supply chain management in linguistic preferences. J. Clean. Prod. 2013, 40, 22-31. [CrossRef]

67. Scur, G.; Barbosa, M.E. Green supply chain management practices: Multiple case studies in the Brazilian home appliance industry. J. Clean. Prod. 2017, 141, 1293-1302. [CrossRef]

68. Figge, F.; Hahn, T. Is green and profitable sustainable? Assessing the trade-off between economic and environmental aspects. Int. J. Prod. Econ. 2012, 140, 92-102. [CrossRef]

69. Thollander, P.; Backlund, S.; Trianni, A.; Cagno, E. Beyond barriers-A case study on driving forces for improved energy efficiency in the foundry industries in Finland, France, Germany, Italy, Poland, Spain, and Sweden. Appl. Energy 2013, 111, 636-643. [CrossRef]

70. Liu, P.; Zhou, Y.; Zhou, D.K.; Xue, L. Energy Performance Contract models for the diffusion of green-manufacturing technologies in China: A stakeholder analysis from SMEs' perspective. Energy Policy 2017, 106, 59-67. [CrossRef]

71. Mittal, V.K.; Sangwan, K.S.; Herrmann, C.; Egede, P.; Wulbusch, C. Drivers and Barriers of Environmentally Conscious Manufacturing: A Comparative Study of Indian and German Organizaionts; Leveraging Technology for a Sustainable World; Springer: Berlin/Heidelberg, Germany, 2012; pp. 97-102.

72. Henriques, J.; Catarino, J. Motivating towards energy efficiency in small and medium enterprises. J. Clean. Prod. 2016, 139, 42-50. [CrossRef]

73. Parker, C.M.; Redmond, J.; Simpson, M. A review of interventions to encourage SMEs to make environmental improvements. Environ. Plan. C Gov. Policy 2009, 27, 279-301. [CrossRef]

74. Lee, K.E.; Mokhtar, M.; Goh, C.T.; Singh, H.; Chan, P.W. Initiatives and challenges of a chemical industries council in a developing country: The case of Malaysia. J. Clean. Prod. 2015, 86, 417-423. [CrossRef]

75. Yang, J.; Wang, J.; Wong, C.W.; Lai, K.H. Relational stability and alliance performance in supply chain. Omega 2008, 36, 600-608. [CrossRef]

76. Govindan, K.; Diabat, A.; Shankar, K.M. Analyzing the drivers of green manufacturing with fuzzy approach. J. Clean. Prod. 2015, 96, 182-193. [CrossRef] 
77. Zheng, D.; Shi, M. Multiple environmental policies and pollution haven hypothesis: Evidence from China's polluting industries. J. Clean. Prod. 2017, 141, 295-304. [CrossRef]

78. Neto, G.C.O.; Leite, R.R.; Shibao, F.Y.; Lucato, W.C. Framework to overcome barriers in the implementation of cleaner production in small and medium-sized enterprises: Multiple case studies in Brazil. J. Clean. Prod. 2016, 142, 50-62. [CrossRef]

79. Darnall, N.; Jolley, G.J.; Handfield, R. Environmental management systems and green supply chain management: Complements for sustainability? Bus. Strategy Environ. 2008, 17, 30-45. [CrossRef]

80. de Sousa Jabbour, A.B.; Jabbour, C.J.; Latan, H.; Teixeira, A.A.; de Oliveira, J.H. Quality management, environmental management maturity, green supply chain practices and green performance of Brazilian companies with ISO 14001 certification: Direct and indirect effects. Transp. Res. Part E 2015, 74, 139-151. [CrossRef]

81. Diabat, A.; Govindan, K. An analysis of the drivers affecting the implementation of green supply chain management. Resour. Conserv. Recycl. 2011, 55, 659-667. [CrossRef]

82. Farris, D.R.; Sage, A.P. On the use of interpretive structural modeling to obtain models for worth assessment. Comput. Electr. Eng. 1975, 2, 149-174. [CrossRef]

83. Warfield, J.N. Societal Systems: Planning, Policy, and Complexity; Wiley: New York, NY, USA, 1976.

84. Sage, A. Interpretive Structural Modeling: Methodology for Large Scale Systems; McGraw-Hill: New York, NY, USA, 1977.

85. Govindan, K.; Pokharel, S.; Kumar, P.S. A hybrid approach using ISM and fuzzy TOPSIS for the selection of reverse logistics provider. Resour. Conserv. Recycl. 2011, 55, 493-494. [CrossRef]

86. Lai, K.H.; Bao, Y.; Li, X. Channel relationship and business uncertainty: Evidence from the Hong Kong market. Ind. Mark. Manag. 2008, 37, 713-724. [CrossRef]

87. Zhu, Q.; Sarkis, J.; Lai, K.H. Green supply chain management innovation diffusion and its relationship to organizational improvement: An ecological modernization perspective. J. Eng. Technol. Manag. 2012, 29, 168-185. [CrossRef]

88. Freeman, E.R. Strategic Management: A Stakeholder Approach; Pitman: Boston, MA, USA, 1984.

89. Reinhardt, F.L. Bringing the environment down to earth. Harv. Bus. Rev. 1999, 77, 149-157. [PubMed]

90. Lee, S.Y.; Klassen, R.D. Drivers and enablers that foster environmental management capabilities in small- and medium-sized suppliers in supply chains. Prod. Oper. Manag. Soc. 2008, 17, 573-586. [CrossRef]

91. Delmas, M.A.; Montiel, I. The Adoption of Iso 14001 within the Supply Chain: When Are Customer Pressures Effective? ISBER Publications, Paper 10; Institute for Social, Behavioral, and Economic Research: Santa Barbara, CA, USA, 2007; Available online: http:/ / repositories.cdlib.org/isber/publications/10 (accessed on 23 February 2021).

92. Handfield, R.; Walton, S.V.; Seegers, L.K.; Melnyk, S.A. Green value chain practices in the furniture industry. J. Oper. Manag. 1997, 15, 293-315. [CrossRef]

93. Backer, L. Engaging stakeholders in corporate environmental governance. Bus. Soc. Rev. 2007, 112, 29-54. [CrossRef]

94. Zhu, Q.; Sarkis, J. The moderating effects of institutional pressures on emergent green supply chain practices and performance. Int. J. Prod. Res. 2007, 45, 4333-4355. [CrossRef]

95. Darnall, N.; Henriques, I.; Sadorsky, P. Do environmental management systems improve business performance in an international setting? J. Int. Manag. 2008, 14, 364-376. [CrossRef]

96. Hoffman, A. Competitive Environmental Strategy: A Guide to the Changing Business Landscape. Island Press: Washington, DC, USA, 2000. 